Report

\title{
Destructive accidents / incidents and non-destructive inspection technologies
}

\section{破壊事故・インシデントと非破壊検査技術}

\author{
Takanori KOBUNAI \\ Hihakaikensa Co.,Ltd Niigata Office, House persimmon 3, 1-6-15-1 Nuttarihigashi, Chuuou-ku, \\ Niigata-shi, Niigata, 950-0075 Japan \\ TEL:x81-025-385-7725 FAX: x81-025-385-7728 e-mail: kobunai@hihakaikensa.co.jp \\ (Received 24 February, 2020)
}

Destruction accidents mean not only machine troubles but also human errors. An incident is reoffered to as a situation just before accidental situation. The industry has experienced unexpected accidents and destructions, and has become the cornerstone of technological development in each field. In this issue, we will introduce our experiences in the non-destructive inspection industry and technological advances.

Keywords : Non-destructive inspection, Accidents, Incidents

\section{INTRODUCTION}

\section{I-A. History of Non-destructive inspection}

「非破壊検査」という言葉を御存じだろうか。

非破壊検査とは、物を壊さずに検査をするという意味 であるが、弊社は「非破壊検査」という言葉がそのまま 会社名になっている。1

我が国の高度経済成長期と言われている時期、1957 年 に弊社は会社設立、以後、水力発電所の検査、東海道新 幹線の軌道溶接部の検査、石油精製設備や火力、原子力 発電設備、石油やガスの備蓄タンクなどの法定検査や自 主検査、時には政府関係からの依頼、そして製造や生産 に必要な設備を保有している民間事業者からの相談や依 頼に対応し続けて 60 年を越え、現在に至る。

そして、今日では数多の検査会社、検査会社の作業員 達が、北は北海道、南は沖縄、そして国内だけにとどま らず、世界の各地で日々、活躍している。

「非破壊検査」を業としている人達は、戦後、我が国 の産業とインフラストラクチャーの発展と共に歩み、そ して、設備の安定運転や維持管理が結果的に我が国の産 業、経済や国民の生活を守ることに寄与するということ を肌で感じながら、「安全の防人」として、歩み続けた歴 史があり、そしてこれからも我々はその歴史と存在意義 を守り続けていくことになる。

\section{I-B. Serious accidents / Incidents}

産業界だけでなく日常の生活の中で、我々は「想定外 の事故」を数多く経験してきた。また、想定外の事故に なる前に、発見されて、事なきを得たことは、多分、数 えきれないくらいある。

我が国では、明らかな重大事故（例えば、燃料設備の 火災、爆発事故など）は、当日の号外、ニュース報道、 あるいは翌日の新聞で知ることが多い。重大事故では無 くても、事故に至れば人命を失う可能性がある事象（例 えば、自動車のリコールや航空機関連のトラブル、鉄道 運行に支障を来すような事象）も報道を通じて知ること が多い。

「事故(アクシデント)」に至る前の事象のことを、「イ ンシデント」というが、この聞きなれない言葉は、日本 産業規格 JIS Q 22300 社会セキュリティー用語で定義さ れている。2

JIS Q 22300 は ISO 22300: Vocabulary の IDT(完全一致) とされているため、インシデントの定義は、「中断・阻害、 損失、緊急事態、危機に、なり得るまたはそれらを引き 起こし得る状況」と記載されている。

簡単に言うと、インシデントとは、「事故（アクシデン 卜) が発生する一歩手前の状況」ということだが、用語、 定義では、事故とインシデントは異なるものであるため、 区別されている。 
区別はされているが、我々は過去に起きた設備の損傷、 事故やインシデントを経験してきた過去があり、同じ失 敗を繰り返さないために、決められた法律や規則が作ら れ、事故やインシデントを未然に防ぐ目的の一つとして 非破壊検査の技術が利用されることがある。

\section{I-C. Various Non-destructive test methods}

非破壊試験の技術は、対象とするきずや欠陷、発生部 位により使い分ける。

大きく分けて、

・内部のきずを見つける（放射線、超音波）

・表層部のきずを見つける（磁気、渦電流）

・表面のきずを見つける（液体浸透）

となっている。その他、進展中のきずを見つける音響を 利用した方法やひずみゲージを貼り付けて変形の度合い を測定する方法などもある。

これらの非破壊試験技術については、現在、社団法人 日本非破壊検查協会で資格の認証試験が行われている。 現在では、「JIS Z 2305 非破壊試験技術者の資格および認 証」という規格により、資格取得のための訓練や教育を 経て各種の資格を取得する仕組みとなっている。3

\section{ADVANCES IN NON-DESTRUCTIVE TESTING TECHNOLOGY}

\section{II-A. Radiographic testing}

放射線透過試験とは、物質を透過する放射線のうち、 エックス線やガンマ線を使用し、試験体に照射させてフ イルムに感光させる。

そのフィルムに投影させた像を見て、溶接線内部に欠 陥が無いか、欠陥があった場合、判定基準に従って合否 判定をする試験のことを言う。

これは、定期健康診断で御馴染みの胸部レントゲン写 真撮影と同様だが、近年、医療現場では感光体として、 フィルムは殆ど使われていない。

フィルムが使われなくなった理由として、

・コンピュータ技術の進化（情報の処理量の向上）

・感光体の変化

が挙げられる。

フィルムの代わりに使われる感光体として、「イメージ ングプレート」というものがある。これをフィルムの代 わりに感光体として使用することにより、「フィルムの現 像」という作業が無くなった。また、画像は読み取り装 置で処理するデジタルデータなので、記録の保存性の向 上や、画面上での濃度調整が可能となった。

その他、空港などでは、ベルトコンベヤーの上に置い た荷物を係員がリアルタイムで画像確認する「据置型の
エックス線透視装置」持ち運び可能でリアルタイムに透 視画像を見ることが出来る「フラットパネル」、病院でも 近年、利用されている CT スキャンと同様に被写体の内 部の情報まで判る「三次元マイクロフォーカス X 線 CT」 は、台に設置した試験体を回転させながら取り込んだ情 報を集積し、三次元画像の表示や、拡大、縮小、内部の 断面などを確認出来るようになった。

ただし、「三次元マイクロフォーカス X 線 CT」は手で 持ち運べるような部品や基盤など比較的小さな物で、 $\mathrm{X}$ 線が透過可能な厚さや材質の物だけしか適用は出来ない。

このように、放射線透過試験の基本的な部分、原理は 変わっていないが、技術の進歩と共に得られたデータの 処理方法が変わってきている。

以上、放射線透過の技術は非常に便利で誰が見ても分 かる記録をアウトプット出来るが、工業の現場では、

・X 線やガンマ線が透過しにくい材質や厚さ

・感光体を配置出来ない

などの制約があると残念ながら利用が出来ない事も多い。 そのような場合は、放射線透過試験よりも効率が良く、 制約の少ない手法として超音波探傷試験が用いられるこ と多い。

\section{II-B. Ultrasonic testing}

超音波探傷試験は、

・超音波探傷器

・超音波探触子

・接触媒質

・装置を調整する試験片

以上、4 点が揄えば探傷や測定が可能である。

試験体に超音波を垂直方向に入射する垂直探傷法では、 鋼材の厚さの測定や、鋼材の中にあるきずの検出、位置 を特定することが出来る。また、超音波を斜めに入射す る斜角探傷法では、鋼材や溶接部にあるきずや、板厚方 向に進展しているき裂の有無を調べたりすることが出来 る。

試験体にき裂が発生している場合、斜角探傷を利用し、 表示画面に表示される波形の挙動や特徴を熟知すると、 き裂の高さ方向の寸法を測定することも出来る。この方 法を「端部エコー法」といい、日本非破壊検査協会では、 この技術について、「端部エコー法によるきず高さ測定 (NDIS 2418)」という規格を制定している。4

しかし、この方法は、き裂高さの測定結果に誤りがな いかについて、確認する方法が無い。確認方法としては、 記録を持って現地・現物で技術者が、超音波の波形を見 せて立会確認を受けることか、現物を切断して目視で確 認する方法しか無いが、過去には原子力発電所の重要な 
系統の配管溶接部に亀裂があることが判明し、立会確認 を受けた後、実際に配管を切断してき裂の高さを測定し た結果、報告された測定值よりもはるかに大きかったと いう事象も数件報告されている。 5

そのような背景があり、一定レベルの精度でき裂高さ 測定が出来る技術者の認定を出来る仕組みが必要だとい うことで出来た規格が、超音波探傷試験システムの性能 実証における技術者の資格および認証(NDIS 0603)」であ る。 6

この規格は、

・使用する超音波探傷装置

- 手順書

・検査員の技量

を一括した形で行われ、試験体に付与されているき裂の 検出性、き裂高さの寸法測定精度を判定するシステムと して認証するという資格であり、我が国では、一定水準 以上の精度でき裂高さ測定技術を持っている技術者、有 資格者という事となる。

この資格は、高額な受験料（1 回の申請料と受験料の 合計が一人 110 万円） と適用範囲が原子力発電設備のう ち、「オーステナイト系ステンレス鋼 (ステンレス鋳鋼を 除く）突合せ溶接部」という極めて限られた部位のき裂 高さ測定」という理由もあり、有資格者数は国内で 20 人 程度と、非常に少ない。

超音波を利用したき裂の高さ測定は、難しい非破壊検 査の技術の一つだが、近年は、技術の進歩により従来の 波形を画像化することが可能となった。

これを「フェイズドアレイ技術」といい、複数の素子 のパルスを電子制御することによって得られた超音波波 形をリアルタイムに画像化する超音波探傷装置である。

その他、弊社では据置型の超音波探傷試験装置のシス テムで、「超音波水浸法」を利用した「超音波法による金

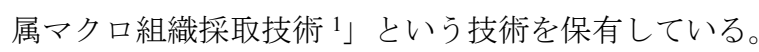

これは、現場向けの技術では無いが、水槽に入るくら いの大きさの試験体であれば、超音波探触子の制御と得 られた情報により、溶接部近傍の金属組織の状況を画像 化することを可能とした技術で、弊社の HP で紹介して いる。

以上、非破壊試験方法のうち、放射線と超音波を利用 した非破壊試験方法について、技術の進歩も含めて紹介 した。非破壊検査の技術は、今後も事故やインシデント を経験しながら、技術の発展や要求に応じて、種類が増 えたり、進歩を続けていくことになるだろう。

\section{IMMINENT DANGER AND NON- DESTRUCTIVE INSPECTION TECHNOLOGY}

最後に身近にある危険と適用される非破壊検査技術に ついて紹介する。改めて気が付くことは少ないが、実は 我々の身の回りには、「危険な状態」であるものが溢れて いる。危険な状態とは、

・立っているものは 倒れる

・吊っているものは 落下する

・高いところにあるものは 落ちる

・丸いものは 転がる

・動いているものには 挟まれる

・回転しているものには 巻き込まれる

といった状態で、時と場合によっては身近にあるものが 事故の原因となる。

2018 年 6 月、大阪北部地震で、小学校へ登校途中の女 子览童が倒壊したブロック塀の下敷きになった事故 7 が発生した。我が国で地震によるブロック塀の倒壊、そ して死亡事故はこれが初めてではない。

我が国でブロック塀が設置され始めたのは昭和 30 年 代以降と思われるが、このような事故が発生した結果、 耐震基準の見直しや施工方法の変更はあった。

しかし、この地震で倒れたブロック塀の構造について 確認した結果、「違法建築物であった」というニュースが 流れ、その後直ちに国土交通省からブロック塀の点検を 行う時の、点検のチェックポイントが公表された。

その点検内容の一つにブロック塀内部の鉄筋の状況確 認については、

・塀の中に規定サイズ以上の鉄筋が、縦横共に規定 間隔以内の寸法で配筋されていて、縦筋は壁頂部 と基礎部にかぎ掛けされていること といった記載がされていた。

このような直接目視で確認出来ない、内部状況に関す る確認の要求があった場合、先程紹介した「放射線透過 写真撮影」や、「鉄筋レーダー法」という電磁波を利用し た非破壊試験技術が用いられる。1

放射線透過写真撮影は、放射線管理や一般市民が生活 している市街地などで作業が可能かという制約の他、作 業の効率が非常に悪いという条件が常に付きまわるが、 透過写真撮影の画像として誰でも見てわかる証拠が残せ るという利点はある。

しかし、急に全国一斉にブロック塀の点検を行うため には、人 (技術者)、装置の台数、行政が準備出来る費用 が膨大になるため、現実的な対応としては、「鉄筋レーダ 
一法」を用いてブロック塀内部の配筋状況を把握するこ とになる。

その他、立っているものが倒れた事象として、2018 年 8 月、淡路市で台風の影響による風力発電設備の倒壊、8 吊っているものは落下した事象や事故で、2011 年 3 月、 東日本大震災による公共施設や体育館の天井が落下した 事象や、2012 年 12 月、中央自動車道笹子トンネル天井 板落下事故 9 がある。

高いところからものが落ちる事故や事象は、今でも 時々、ニュース報道でも流れ、丸いものが転がって起き た事故や事象については、走行中の車のタイヤが外れる ということが統計を見ると毎年発生しており、トラック から外れた大きなタイヤが、転がってきて人にぶつかり 死亡したという痛ましい事故もあった。

その他、動いているものに挟まれる、回転しているも のに巻き込まれるという事故はほぼ毎月、労働災害報告 の中で紹介がある。

\section{CONCLUSION}

今回は事故やインシデントに非破壊検查技術がどのよ うに関わってきたのか、技術の進歩という点も含めて紹 介してきた。非破壊検査技術は、いろいろな場面で、産 業だけでなく日常生活に近いところでも関わり合いを持 っていることを理解していただけたと思う。

我が国は、自然災害大国であり、四季の中で発生する 台風、大雨、大雪、落雷の他、不定期に各地で起こる地 震や津波、火山噴火がある。そして、近年では高度経済 成長時期に全国各地で造られた設備やインフラストラク チャーの老朽化が懸念されている。
自然災害と身近にある設備の損壊が重なった時、どの ような場所でどのような事故に至るのかは想像がつかな いが、出来れば我々のような非破壊検査の技術者が事故 後の調査などで活躍をしないで済むように、設備、ある いは施設を保有、管理している事業者や自治体は、定期 的な設備点検、設備投資や設備の更新など、事前の対策、 対応を積極的に進めてほしいと願う。

\section{REFERENCES}

${ }^{1}$ Hihakaikensa Co.,Ltd, https://www.hihakaikensa. co.jp/

2 JIS Q 22300 Societal security-Terminology, pp. 3.

3 JIS Z 2305 Non-destructive testing-Qualification and certification of NDT personnel, pp. 8-18.

${ }^{4}$ NDIS 2418 Measurement of flaw height using tip echo technique, pp. 9-12.

5 A. Yamaguchi, Gijutsu-Revew, Vol. 1, pp. 32-35 (2005) (in Japanese).

${ }^{6}$ NDIS 0603 Qualification and certification of personnel for performance demonstration of ultrasonic testing systems, pp. 8-12.

7 Takatsuki City Survey report, http://www.city.ta katsuki.osaka.jp/shisei/profilekeikaku/shingikai/tos hin/tyousaiinkai/1542168822662.html

${ }^{8}$ Awaji City Survey report, http://www.city.awaji.1 g.jp/uploaded/attachment/22705.pdf

${ }^{9}$ Ministry of Land, Infrastructure, Transport and Tourism Survey report, https://www.mlit.go.jp/co mmon/001001299.pdf 